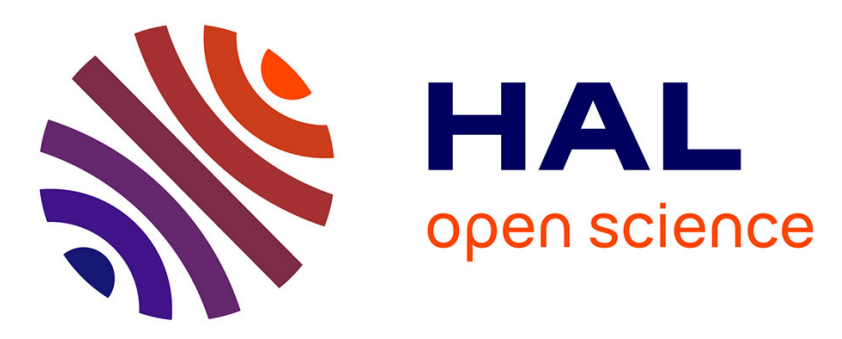

\title{
Genetic diversity of on-farm selected olive trees in Moroccan traditional olive orchards
}

\author{
Ahmed El Bakkali, Hicham Haouane, Amal Hadiddou, Ahmed Oukabli, A., \\ Sylvain Santoni, Sripada M. Udupa, S. M., Patrick van Damme, Bouchaib \\ Khadari
}

\section{To cite this version:}

Ahmed El Bakkali, Hicham Haouane, Amal Hadiddou, Ahmed Oukabli, A., Sylvain Santoni, et al.. Genetic diversity of on-farm selected olive trees in Moroccan traditional olive orchards. Plant Genetic Resources, 2013, 11 (2), pp.97-105. 10.1017/s1479262112000445 . hal-01190677

\section{HAL Id: hal-01190677 https://hal.science/hal-01190677}

Submitted on 1 Sep 2015

HAL is a multi-disciplinary open access archive for the deposit and dissemination of scientific research documents, whether they are published or not. The documents may come from teaching and research institutions in France or abroad, or from public or private research centers.
L'archive ouverte pluridisciplinaire HAL, est destinée au dépôt et à la diffusion de documents scientifiques de niveau recherche, publiés ou non, émanant des établissements d'enseignement et de recherche français ou étrangers, des laboratoires publics ou privés. 


\title{
Genetic diversity of on-farm selected olive trees in Moroccan traditional olive orchards
}

\author{
Ahmed El Bakkali, 2,3,4, Hicham Haouane ${ }^{1,2}$, Amal Hadiddou ${ }^{3}$, \\ Ahmed Oukabli ${ }^{3}$, Sylvain Santoni ${ }^{1}$, Sripada M. Udupa ${ }^{5,6}$, \\ Patrick Van Damme ${ }^{4}$ and Bouchaib Khadari ${ }^{1,7 *}$ \\ ${ }^{1}$ INRA, UMR 1334 Amélioration Génétique et Adaptation des Plantes (AGAP), F-34070 \\ Montpellier, France, ${ }^{2}$ Montpellier SupAgro UMR 1334, AGAP, F-34070 Montpellier, \\ France, ${ }^{3}$ INRA, CRRA-Meknes, UR Amélioration des Plantes et Conservation des \\ Ressources Phytogénétiques (APCRPG), BP 578 Meknes, Morocco, ${ }^{4}$ Ghent University, \\ Faculty of Bioscience Engineering, Department of Plant Production, Coupure Links 653, \\ B-9000 Ghent, Belgium, ${ }^{5}$ ICARDA-INRA Cooperative Research Project, ICARDA, BP \\ 6299, Rabat Morocco, ${ }^{6}$ INRA, CRRA-Rabat, BP 415, Rabat, Morocco and ${ }^{7}$ CBNMED, \\ UMR 1334 AGAP, F-34398 Montpellier, France
}

Received 23 June 2012; Accepted 25 October 2012 - First published online 29 November 2012

\begin{abstract}
Selecting desired agronomic traits may lead to a loss of genetic diversity in crop species. A molecular investigation was conducted to determine how well a set of olive (Olea europaea L.) accessions sampled in Moroccan traditional orchards represented the entire Moroccan olive diversity range. We therefore collected, in traditional agroecosystems from northern and central Morocco, a total of 88 olive trees chosen for their agronomic traits based on local farmers' knowledge. Using 12 SSR loci, 45 trees (51.1\%) had a genotype identical to the 'Picholine Marocaine' variety, while the remaining samples were classified into 27 different SSR profiles. Two categories of genotypes were identified: (i) genotypes closely related to the 'Picholine Marocaine' variety and probably resulting from intensive vegetative propagation from a limited number of clones, and (ii) genotypes displaying a high number of dissimilar alleles which may have originated from selected spontaneous seedlings. A significant difference in allelic richness was revealed between the 28 on-farm selected genotypes and the overall olive diversity, represented by 57 local genotypes, indicating that the on-farm selected trees represented a subsample of Moroccan genetic diversity. This could be explained by the prevalence of 'Picholine Marocaine' in traditional orchards, while some original genotypes with favourable agronomic traits resulting from local farmers' selection were also identified. Applying an ethnobotany approach combined with criteria to fulfil farmers' household needs could be particularly relevant and better explain the obtained results.
\end{abstract}

Keywords: intra-varietal variation; local farmers' knowledge; olive (Olea europaea L.); olive breeding; 'Picholine Marocaine' variety; SSR markers

\section{Introduction}

Olive (Olea europaea L. subsp. europaea) is one of the oldest Mediterranean crops (Zohary and Hopf, 2000). Because of the nutritional value of its products, its economic importance and agroecological resilience, olive is 
cultivated under contrasting environmental conditions in more than 24 countries (Bartolini et al., 1998). In Morocco, olive cultivation is an ancient practice that was further developed during the Roman era (2nd and 3rd centuries AD; Lenoir and Akerraz, 1984). With about 740,000 ha, olive represents more than 55\% of Morocco's current fruit tree orchards, giving it a prominent socioeconomic role. A single variety, 'Picholine Marocaine' (PM), prevails in traditional olive orchards and accounts for about $98 \%$ of the total olive cropping area (Boulouha et al., 1992). Indeed, this variety is highly appreciated by farmers due to its wide array of favourable agronomic traits, i.e. high oil and canned fruit quality and high adaptability to local environmental conditions. However, it also has unwanted traits such as alternate bearing and susceptibility to peacock spot (Spilocaea oleagina Cast.) and verticillium wilt (Verticillium dabliae Kleb.; Barranco et al., 2000). A recent molecular study highlighted broad genetic diversity in Moroccan cultivated olives (Khadari et al., 2008). The identification and characterization of local germplasm could therefore yield information on outstanding accessions that could then be used for the selection of olive trees with more useful agronomic traits, thus offering potential alternatives to PM cultivation.

Climate change, particularly drought risk, pests and diseases are all threatening olive production in Morocco as well as in the Mediterranean Basin. Local varieties represent an important gene pool that could serve as an allele source for improved adaptation and tolerance to many biotic and abiotic stresses. These genetic resources are continuously subject to genetic erosion due mainly to habitat degradation. Selection and conservation of local varieties, by applying local knowledge and farmers' preference criteria, is thus crucial. The results of many studies in several species have revealed the value of participatory varietal selection in maintaining a high level of genetic diversity (Almekinders and Elings, 2001; Zhang et al., 2011). They indicated that farmers' knowledge-based approaches are efficient in identifying high-yielding genotypes with traits of interest for their specific cropping environment, therefore highlighting farmers' know-how in selecting and conserving local genetic resources (Fufa et al., 2007, 2010).

Here, we used SSR markers to study genetic diversity in a collection of olive trees from different traditional agroecosystems in Morocco, featuring interesting agronomic traits that had been selected in situ by local farmers on the basis of their preferred criteria. The estimated diversity was compared with the overall genetic diversity present in Moroccan traditional olive orchards, as previously studied by Khadari et al. (2008). We specifically aimed to: (i) test whether the olive tree samples, selected on the basis of local farmers' knowledge, represented the overall genetic diversity in Morocco; (ii) investigate the genetic relationship between the selected olive trees and the PM variety, and (iii) estimate the extent of genetic diversity within the selected olive trees.

\section{Materials and methods}

\section{Plant material}

Olive tree sampling was conducted in different traditional orchards during the fruit ripening period (October-December). Trees were sampled in nine distinct geographical areas (Fig. 1 and Table 1): North West [Chefchaouen ( 5 trees) and Ouazzane (5)]; North Centre [Taounate (6), Sefrou (7) and Moulay Driss-Zerhoun (11)]; North East [Taza (18) and Outat El-Haj (7)]; Centre South [Er-Rachidia (23)]; Middle Atlas [Khenifra (6)].

A total of 88 accessions (trees), for which the farmers had no denomination, were selected according to the main agronomic traits targeted in olive breeding and which fulfil local farmers' needs: low alternate bearing; high productivity; use for either oil or canned fruit; oil yield (\% fresh matter); fruit size; pulp-to-pit ratio (Supplementary Table S1, available online only at http://journals.cambridge.org). Leaves sampled from each selected olive tree were lyophilized and stored at $-20^{\circ} \mathrm{C}$ for further DNA analysis.

In addition, a set of 57 genotypes previously identified by Khadari et al. (2008) representing the overall olive genetic diversity in Moroccan orchards was analysed using the same set of SSR loci. These genotypes included eight traditional varieties, namely PM, 'Bouchouk', 'Bouchouika', 'Meslala', 'Hamrani', 'Bouchouk Rkik', 'Bouchouk Laghlid' and 'Fakhfoukha', and 49 local genotypes without any specific denomination originating from limited areas often not exceeding the village scale. Moreover, a total of 474 Mediterranean olive genotypes, derived from 13 countries and maintained at the worldwide olive germplasm bank, Marrakech, Morocco (WOGB; Haouane et al., 2011), were used to compare local genotypes with foreign cultivars.

\section{Molecular analysis}

Total DNA was extracted from $40 \mathrm{mg}$ of lyophilized leaves of the sampled trees following the modified Cetyl Trimethylammonium Bromide (CTAB) procedure, as described by Udupa et al. (1999). DNA quality was determined using $1 \%$ agarose gel stained with ethidium bromide. The extracted DNA was quantified using a spectrofluorometer (GENios Plus; Tecan, Grödig, Austria), and was diluted to $20 \mathrm{ng} / \mu \mathrm{l}$.

Twelve nuclear SSR loci were used: ssrOeUA-DCA03; ssrOeUA-DCA04; SsrOeUA-DCA05; SsrOeUA-DCA08; 


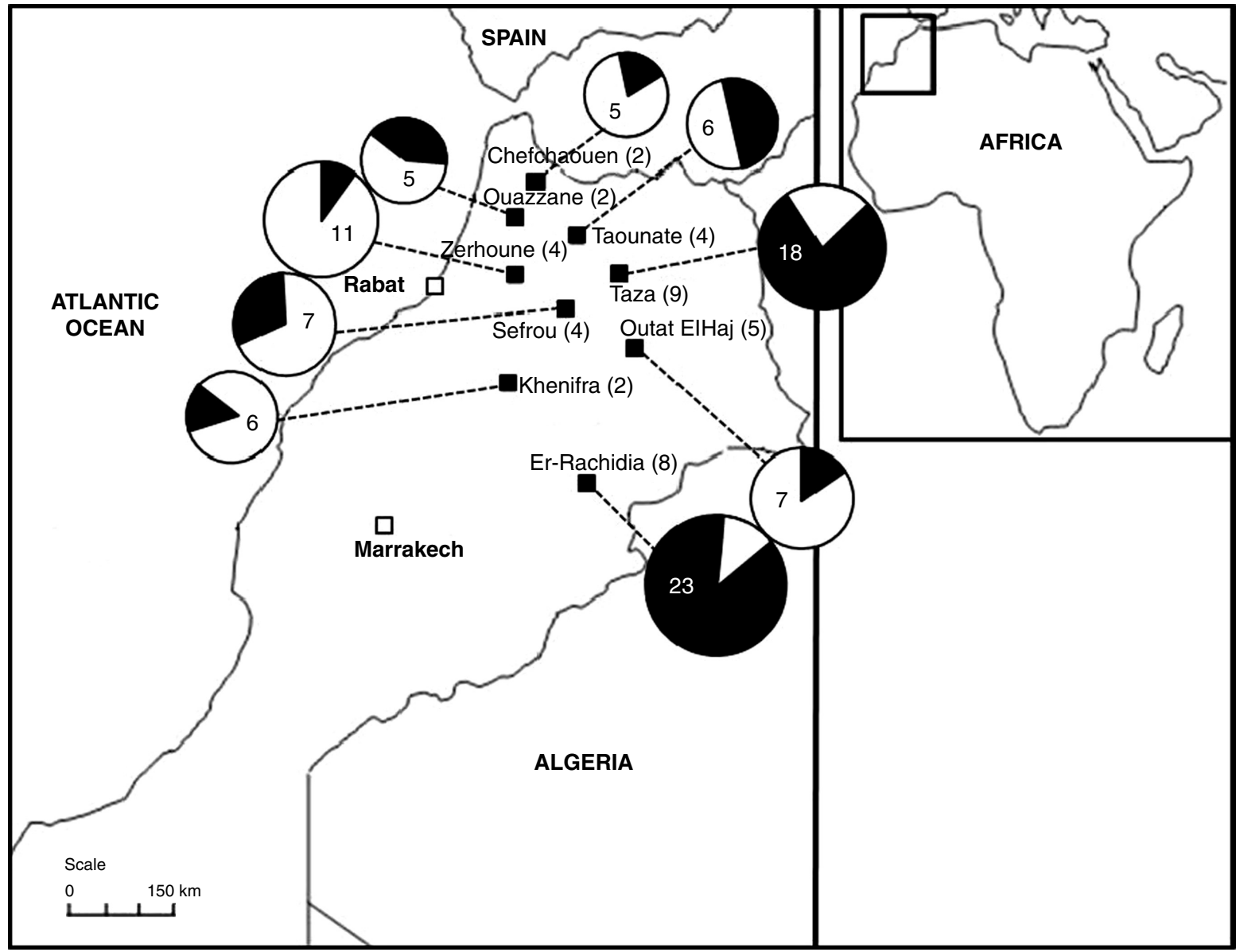

Fig. 1. Sampling areas. Numbers in brackets indicate the number of sampling sites within the area. The pie diagrams indicate the proportion of the PM variety (in black) and olive forms (in white) present at each sampling site. The number within the pie diagrams indicates the number of sampled trees.

ssrOeUA-DCA09; $\quad$ ssrOeUA-DCA11; $\quad$ ssrOeUA-DCA15; ssrOeUA-DCA18 (Sefc et al., 2000); ssrOe-GAPU59 and ssrOe-GAPU71B (Carriero et al., 2002); UDO99-36 (Cipriani et al., 2002); EMO90 (De La Rosa et al., 2002). These SSR loci were selected on the basis of their clear amplification and high polymorphism observed in previous studies (Sarri et al., 2006; Khadari et al., 2008; Baldoni et al., 2009; Haouane et al., 2011). Six and eight among the 12 SSR loci are distributed throughout six and seven linkage groups, respectively (Khadari et al., 2010; Zine El Aabidine et al., 2010). PCR amplification was carried out as described by Haouane et al. (2011). The amplification products were separated using an automated capillary sequencer (ABI prism 3130XL Genetic Analyzer; Applied Biosystems, Foster City, CA, USA) and fragment analysis was performed using GENEMAPPER v3.7 software (Applied Biosystems).

\section{Data analysis}

The number of alleles per locus $\left(N_{\mathrm{a}}\right)$, matching accessions, allelic frequencies $\left(p_{i}\right)$, expected $\left(H_{\mathrm{e}} ; \mathrm{Nei}, 1987\right)$ and observed heterozygosity $\left(H_{\mathrm{O}}\right)$ were estimated using the excel microsatellite toolkit v3.1 (Park, 2001). The discrimination power of each SSR locus $\left(D_{j}\right)$ was calculated as defined by Tessier et al. (1999):

$$
D_{j}=1-\Sigma p_{i}\left[\left(N_{g} p_{i}-1\right) /\left(N_{g}-1\right)\right]
$$

where $p_{i}$ is the frequency of the $i$ th molecular pattern revealed by locus $j$ and $N_{g}$ is the number of genotypes. The genetic distance between genotypes was calculated based on the Nei and Li coefficient (1979) and the dendrogram was drawn based on the UPGMA algorithm (Sneath and Sokal, 1973) using the NTSYS-PC v2.11 package (Rohlf, 2000).

Model-based Bayesian clustering was implemented in structure v2.2 to assess the genetic structure (Pritchard et al., 2000). The program was run using the admixture model with correlated frequencies and ten trials of $1,000,000$ repeats following an introduction period (burn-in/Markov Chain Monte Carlo) of 200,000 repeats for $K=1$ to 10 . The reliability of the number of $K$ clusters was checked using the ad hoc measure $\Delta K$ of Evanno 
et al. (2005), with the R v2.13.0 program (R Development Core Team, 2011), and the similarity coefficient between runs $\left(H^{\prime}\right)$ for the same $K$ clusters was calculated using the CLUMPP program (Jakobsson and Rosenberg, 2007).

\section{Results}

Using the 12 SSR loci, the 88 on-farm selected olive trees were classified into 28 distinct SSR profiles (Table 1). A total of 60 alleles were revealed, ranging from 3 to 12 per locus, with an average of five alleles per locus (Table 2). The analysis of the 57 local genotypes previously defined by Khadari et al. (2008) revealed 139 alleles, ranging from 4 to 22 per locus, with a mean of 11.6 alleles per locus (Table 2). Among the 60 alleles detected in the 28 selected genotypes, 55 alleles were observed in the 57 local genotypes. When examining the relationships between the 57 local genotypes and the 28 SSR profiles, two genotypes occurred in both datasets, i.e. the PM variety and selected olive no. 13 (similar to local olive no. 10). The comparison of the 83 identified genotypes, both local and selected genotypes, with Mediterranean genotypes indicated that all alleles revealed in the present study were present in WOGB Marrakech, and there was no full matching with respect to the 12 SSR loci when comparing the Moroccan genotypes and foreign cultivars.
Among the 88 sampled trees, 45 (51.1\%) were found to share the same profile, previously defined as the PM variety. The prevalence of this variety ranged from 10\% in the Moulay Driss-Zerhoun area to $87 \%$ in Er-Rachidia (Fig. 1 and Table 1). All 27 genotypes differing from the PM variety were each found at only one sampling site, except for six genotypes that were found at different locations; selected olive no. 1, 2, 3, 4, 5 and 6 were noted six, two, two, three, two and five times, respectively (Table 1).

For the 28 on-farm selected genotypes, the observed heterozygosity $\left(H_{\mathrm{O}}\right)$ ranged from 0.07 to 1 and the expected heterozygosity $\left(H_{\mathrm{e}}\right)$ ranged from 0.07 to 0.8 , with an average of 0.83 and 0.53 , respectively, while for the 57 local genotypes, $H_{\mathrm{O}}$ ranged from 0.59 to 0.98 and $H_{\mathrm{e}}$ from 0.52 to 0.86 , with an average of 0.76 and 0.75 , respectively (Table 2). For each SSR locus, the discrimination power $\left(D_{j}\right)$ ranged from 0.52 at EMO90 to 0.95 at DCA9, with a mean of 0.8 . Based on $D_{j}$, eight out of the 12 SSR loci were able to discriminate total genetic diversity [selected olive (28) and local olive (57); Supplementary Table S2, available online only at http://journals.cambridge.org]. Allelic richness $\left(A_{\mathrm{r}}\right)$, computed at 28 individuals of the standardized $G$ value using the ADZE program (Szpiech et al., 2008), was significantly higher in the 57 local genotypes than the value observed in the 28 on-farm selected genotypes

Table 1. Olive forms within each of the sampling areas and geographical zones

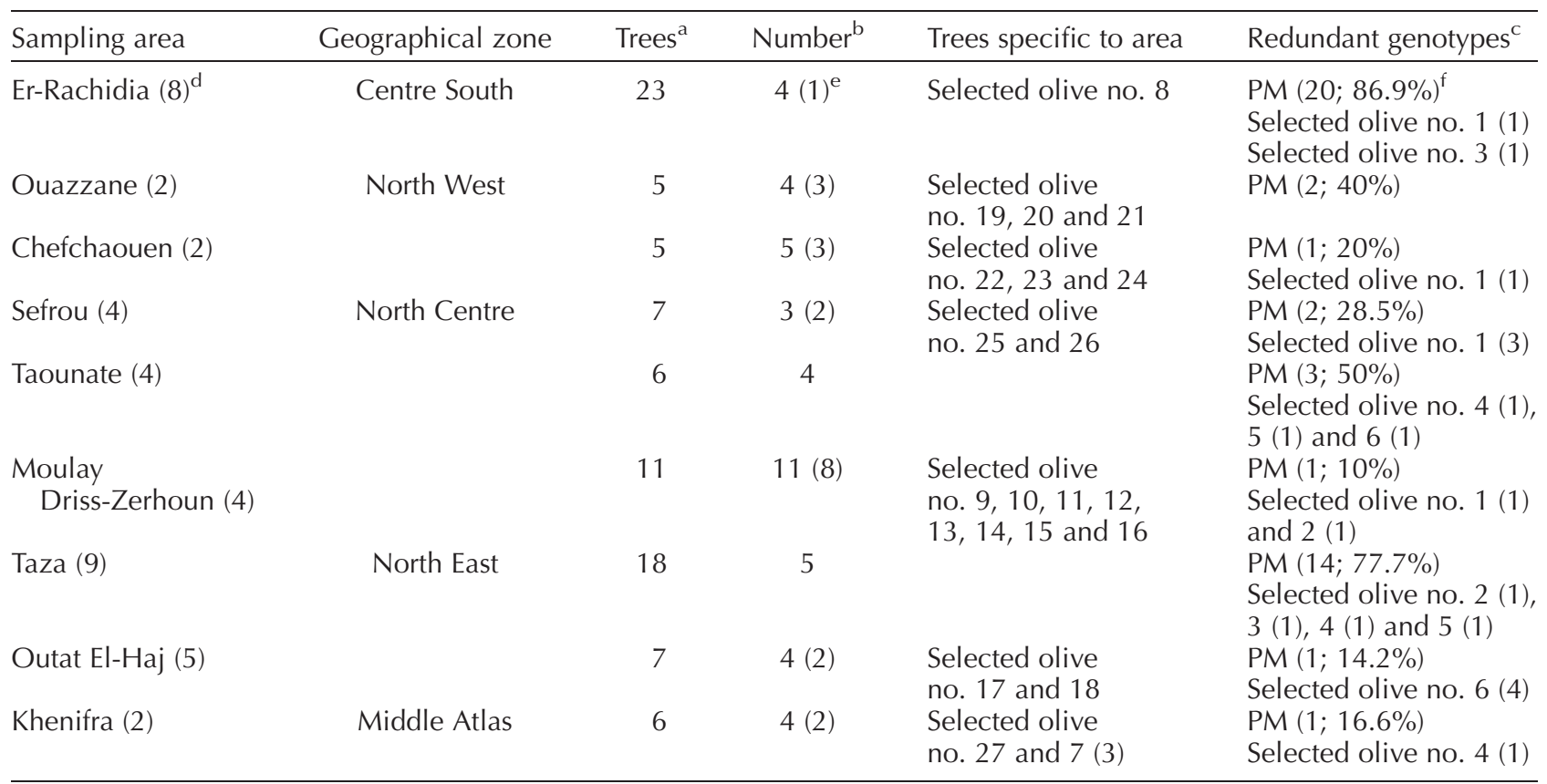

PM, Picholine Marocaine.

${ }^{a}$ Number of studied trees. ${ }^{b}$ Number of trees genetically different per area. ${ }^{\mathrm{c}}$ Genotypes observed in different sampling areas.

${ }^{\mathrm{d}}$ Number of studied sites. ${ }^{\mathrm{e}}$ Number of trees specific to one area. ${ }^{\mathrm{f}}$ Number of accessions observed as PM within each geographical zone and proportion. 
(Mann-Whitney $U$ test, $P<0.01$, two-tailed; Supplementary Table S3, available online only at http://journals. cambridge.org).

Two range sizes for dissimilar alleles were noted among the 378 pairwise comparisons obtained from the 28 selected genotypes (Fig. 2). The first ranged from 0 to 14, whereas the second had between 16 and 32 dissimilar alleles. Most pairwise comparisons were distinguished by less than 14 dissimilar alleles (275 pairwise SSR profiles; 72.7\%), whereas only 103 pairwise profiles differed by 16 to 32 dissimilar alleles. Otherwise, among the 1596 pairwise comparisons of all 57 local genotypes, only four combinations revealed a difference of one to three alleles (local olive no. 10/ PM; local olive no. 23/PM; local olive no. 42/local olive no. 39; local olive no. 10/local olive no. 23), while $99.7 \%$ (1592) displayed 7 to 38 dissimilar alleles (Fig. 2). The PM variety was distinct from the 27 selected olive genotypes by one to six dissimilar alleles, except for selected olive no. 8, 12, 14, 16, 22 and 24, which were distinct by 31,19, 8, 10, 19 and 17 dissimilar alleles, respectively (Supplementary Figs S1 and S2, available online only at http://journals.cambridge. org). Assuming that no variation occurred in flanking sequences of microsatellites, most variations were observed by a gain or loss of dinucleotide repeat units (Supplementary Table S4, available online only at http://journals.cambridge.org), i.e. a gain of two dinucleotide units and a loss of six at the DCA09 locus for selected olive no. 2 and 26, respectively, and by a loss and gain of two dinucleotide repeat units for selected olive no. 25 at DCA08 and DCA18 loci, respectively. Two among the six highly distinct genotypes from PM, i.e. selected olive no. 22 and 24, were genetically close to the 'Bouchouk' variety (only three dissimilar alleles; Supplementary Fig. S3, available online only at http://journals.cambridge.org). Comparing both the PM variety and highly distinct genotypes from PM (six genotypes) with Mediterranean cultivars revealed that the closest foreign cultivars to these genotypes ranged from 8 to 18 dissimilar alleles, i.e. selected olive no. 8/'Angellina' and 'Frantoio' from Italy were distinct by eight dissimilar alleles and the closest cultivar to the PM variety was found to be 'Negrillo de Estepa' from Spain by ten dissimilar alleles (Supplementary Table S5, available online only at http://journals.cambridge.org).

The results obtained through the STRUCTURE program on 83 unique genotypes indicated that the $K=4$ cluster was the best genetic structure model based on the ad hoc measure of Evanno et al. (2005; $\Delta K=113.01)$ and the similarity coefficient between runs for each $K\left(H^{\prime}=0.997\right.$; Jakobsson and Rosenberg, 2007; Supplementary Fig. S4, available online only at http:// journals.cambridge.org). The first cluster included eight genotypes with six traditional varieties ('Bouchouk', 'Bouchouk Rkik', 'Bouchouk Laghlid', 'Bouchouika', 'Fakhfoukha' and 'Meslala'), the second and third included 11 and 22 individuals, respectively, without specific names, whereas the fourth group included geno-

Table 2. Genetic parameters of the 12 SSR loci used in the study for on-farm selected olive (SO), local olive (LO) and total genetic diversity

\begin{tabular}{|c|c|c|c|c|c|c|c|c|c|c|}
\hline & \multirow[b]{2}{*}{ Repeat motif } & \multirow{2}{*}{$\begin{array}{c}\text { Size } \\
\text { range (bp) }\end{array}$} & \multicolumn{2}{|c|}{$N_{a}$} & \multicolumn{2}{|c|}{$H_{\mathrm{o}}$} & \multicolumn{2}{|c|}{$H_{\mathrm{e}}$} & \multicolumn{2}{|c|}{$\begin{array}{c}\text { Total genetic } \\
\text { diversity }^{\mathrm{a}}\end{array}$} \\
\hline & & & $\mathrm{SO}^{\mathrm{b}}$ & $\mathrm{LO}^{\mathrm{c}}$ & $\mathrm{SO}^{\mathrm{b}}$ & $\mathrm{LO}^{\mathrm{c}}$ & $\mathrm{SO}^{\mathrm{b}}$ & $\mathrm{LO}^{\mathrm{C}}$ & $N_{a}$ & $D_{j}$ \\
\hline ssrOeUA-DCA03 $^{\mathrm{d}}$ & $(\mathrm{GA})_{19}$ & $229-260$ & 3 & 9 & 1.00 & 0.754 & 0.559 & 0.764 & $9(3)^{\mathrm{e}}$ & 0.799 \\
\hline ssrOeUA-DCA04 $^{\text {d }}$ & $(\mathrm{GA})_{16}$ & $124-193$ & 5 & 22 & 0.178 & 0.596 & 0.202 & 0.834 & $23(4)$ & 0.858 \\
\hline ssrOeUA-DCA0 $^{\text {d }}$ & $(\mathrm{GA})_{15}$ & $192-214$ & 3 & 10 & 0.071 & 0.684 & 0.07 & 0.625 & $10(3)$ & 0.723 \\
\hline ssrOeUA-DCA08 ${ }^{d}$ & $(G A)_{18}$ & $125-164$ & 5 & 16 & 1.00 & 0.982 & 0.659 & 0.86 & $16(5)$ & 0.868 \\
\hline ssrOeUA-DCA09 ${ }^{\mathrm{d}}$ & $(\mathrm{GA})_{23}$ & $162-209$ & 12 & 20 & 0.857 & 0.929 & 0.801 & 0.868 & $20(12)$ & 0.951 \\
\hline ssrOeUA-DCA $11^{d}$ & $(\mathrm{GA})_{26}(\mathrm{GGGA})_{4}$ & $126-183$ & 7 & 15 & 0.928 & 0.719 & 0.644 & 0.796 & $18(4)$ & 0.854 \\
\hline ssrOeUA-DCA $15^{\mathrm{d}}$ & $(\mathrm{CA})_{3} \mathrm{G}(\mathrm{AC})_{14}$ & $243-266$ & 3 & 4 & 0.964 & 0.631 & 0.551 & 0.706 & $4(3)$ & 0.789 \\
\hline ssrOeUA-DCA $18^{d}$ & $(\mathrm{CA})_{4} \mathrm{CT}(\mathrm{CA})_{3}(\mathrm{GA})_{19}$ & $161-187$ & 7 & 12 & 1.00 & 0.912 & 0.690 & 0.845 & $12(7)$ & 0.842 \\
\hline ssrOe-GAPU $59^{f}$ & $(\mathrm{CT})_{9}$ & $209-233$ & 3 & 8 & 1.00 & 0.649 & 0.542 & 0.666 & $8(3)$ & 0.757 \\
\hline ssrOe-GAPU71B ${ }^{f}$ & $\mathrm{GA}(\mathrm{AG})_{6}(\mathrm{AAG})_{8}$ & $130-160$ & 5 & 6 & 1.00 & 0.964 & 0.622 & 0.799 & $6(5)$ & 0.841 \\
\hline UDO99-36 & $(\mathrm{GT})_{19}(\mathrm{AG})_{5}$ & $134-166$ & 4 & 12 & 1.00 & 0.754 & 0.560 & 0.772 & $13(3)$ & 0.845 \\
\hline EMO90 ${ }^{\mathrm{h}}$ & $(C A)_{10}$ & 178-191 & 3 & 5 & 1.00 & 0.631 & 0.526 & 0.528 & $5(3)$ & 0.52 \\
\hline Mean & - & - & 5 & 11.6 & 0.833 & 0.767 & 0.535 & 0.755 & $12(4.58)$ & 0.803 \\
\hline Total & - & - & 60 & 139 & - & - & - & - & $144(55)$ & - \\
\hline
\end{tabular}

$N_{\mathrm{a}}$ number of alleles observed; $D_{j}$, power of discrimination; $H_{\mathrm{e}}$ expected heterozygosity; $H_{\mathrm{o}}$, observed heterozygosity.

${ }^{a}$ Genetic parameters calculated on 83 unique genotypes representative of the total genetic diversity. ${ }^{b}$ Genetic parameters calculated on selected olive (28 SSR profiles). ${ }^{c}$ Genetic parameters calculated on local olive (57 local genotypes identified

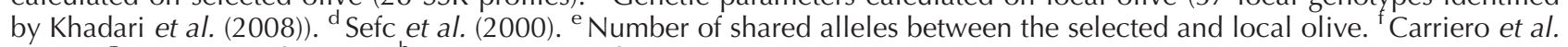
(2002). ${ }^{\mathrm{g}}$ Cipriani et al. (2002). ${ }^{\mathrm{h}}$ De La Rosa et al. (2002). 


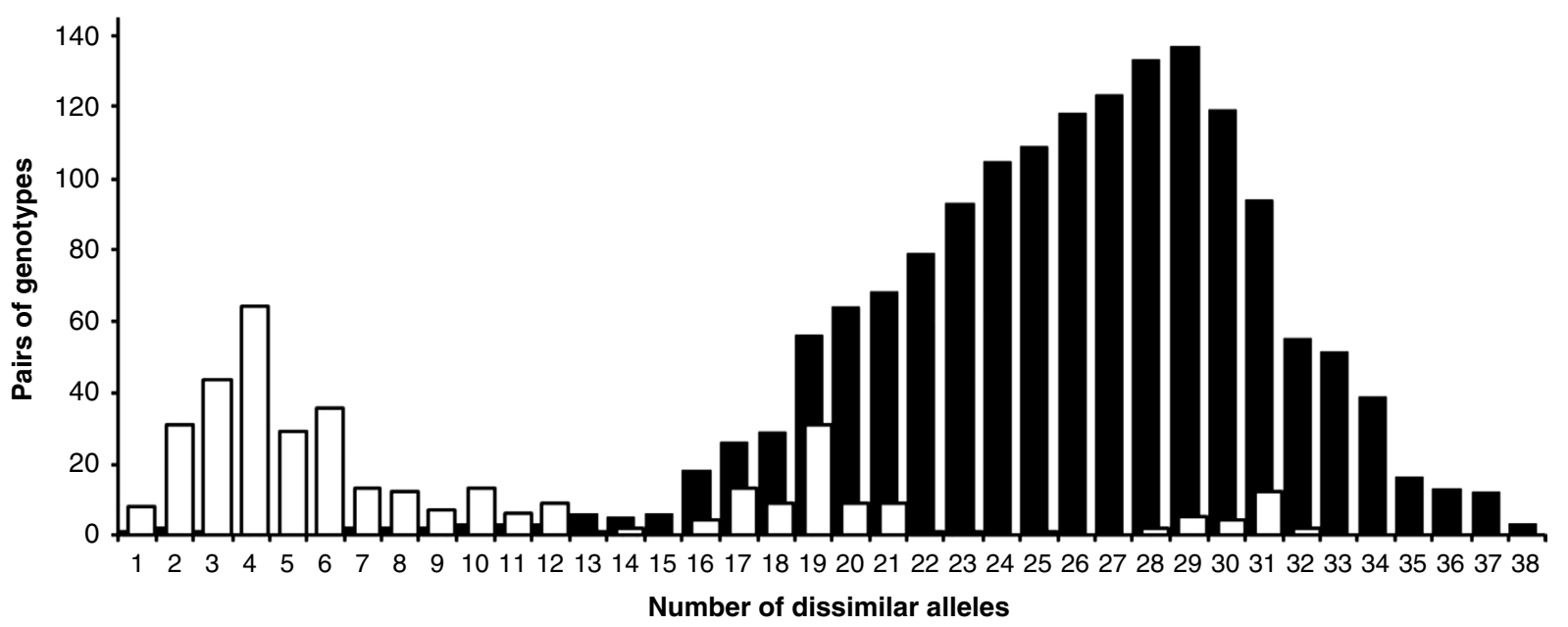

Fig. 2. Frequency distribution of dissimilar alleles for all pairwise combinations between the selected olive genotypes (28, in white) and the local genotypes (57, in black). For the 28 SSR profiles, most pairwise comparisons were distinguished by less than 14 dissimilar alleles $(72.7 \%)$, while for the 57 genotypes, $98.1 \%$ of pairwise comparisons had more than 14 dissimilar alleles.

types closely related to PM (Table 3; Fig. 3; Supplementary Table S6, available online only at http://journals. cambridge.org).

\section{Discussion}

A significant loss of genetic diversity was revealed to be likely due to the selection process performed using local farmers' knowledge when compared with the sampling approach used in Khadari et al. (2008). This loss of diversity could be explained by the selection pressure induced by past farming practices, and also by the sampling strategy adopted for collecting olive trees (i.e. selection for desired agronomic traits). Indeed, Padula et al. (2008) demonstrated a significant effect of environmental conditions on the major agronomic traits used in the present study (fruit size, pulp-to-pit ratio, fruit yield and oil content). Taking into account our experimental design (one tree per site, trait monitoring over 1-2 years) and the lack of quantitative assessment of the environmental versus genotypic effects on the used traits, we consider that, rather than selection pressure, this loss of diversity could be explained more by the prevalence of the PM variety and possible samplinglinked distortion.

When focusing on the selected olive trees, the results were quite similar (51.1 and 52\%, respectively) to those obtained by Khadari et al. (2008) in terms of the number of trees displaying the same genetic profile as the PM variety, thus confirming its prevalence in Moroccan traditional orchards. A narrow genetic base within the on-farm selected olive trees was detected, with accessions being closely related or identical to the PM variety, clearly constituting a homogeneous subsample within the global olive diversity in traditional orchards. These genotypes can be considered as sports mutations of the PM variety and may have arisen as a result of an accumulation of somatic mutations in microsatellite motif repeats. As PM is considered to be a partially self-compatible variety (Barranco et al., 2000), a self-crossing hypothesis to explain the occurrence of closely related genotypes to PM is not excluded. However, a more plausible hypothesis of the clonal variation origin is proposed based on the following reasons: (i) the SSR profiles of the closely related genotypes do not reflect self-crossing segregation; (ii) olive tree is a highly heterozygous species (Green and Wickens, 1989) and very sensitive to inbreeding depression, probably leading to very limited fitness of self-crossed olive trees; (iii) the observed heterozygosity $\left(H_{\mathrm{O}}\right)$ of the PM variety is 0.83 , whereas the $H_{\mathrm{O}}$ noted for closely related genotypes ranged from 0.75 to 0.91 , indicating their high heterozygosity, but this level cannot have been the result of self-fertilization; (iv) most variations were noted for loci with dinucleotides and abundant GA repeat units; several studies have reported that such loci are more susceptible to mutation and slippage (Chakraborty et al., 1997; Kruglyak et al., 1998; Schug et al., 1998; Bachtrog et al., 2000).

Clonal variation was also observed for a local traditional variety, i.e. 'Bouchouk', and has already been reported in olive, including relict olive trees in the Hoggar Mountains (Cipriani et al., 2002; Lopes et al., 2004; Baali-Cherif and Besnard, 2005; Khadari et al., 2008), and in other fruit crops such as grapevine (Ibanez et al., 2009) and Fig. (Achak et al., 2010). Two key elements could explain the occurrence of sports mutations in the PM variety: (i) the prevalence of PM in Morocco and adjacent regions (PM is also known as 'Sigoise' in western Algeria and 'Canivano 
Table 3. Number and proportion of genotypes of both datasets, selected olive (28 genotypes) and local olive (57 genotypes), assigned to the four clusters identified by structure

\begin{tabular}{|c|c|c|c|c|c|c|c|c|c|c|}
\hline & \multirow{2}{*}{$\begin{array}{l}\text { Genotype } \\
\text { number }\end{array}$} & \multirow{2}{*}{$\begin{array}{l}\text { Assigned } \\
\text { genotypes }\end{array}$} & \multicolumn{2}{|c|}{ Cluster 1} & \multicolumn{2}{|c|}{ Cluster 2} & \multicolumn{2}{|c|}{ Cluster 3} & \multicolumn{2}{|c|}{ Cluster 4} \\
\hline & & & $N$ & $\%$ & $N$ & $\%$ & $N$ & $\%$ & $N$ & $\%$ \\
\hline Selected olive & 28 & 25 & 3 & 10.7 & & & & & 22 & 78.5 \\
\hline Local olive & 57 & 44 & 8 & 14 & 11 & 19.3 & 22 & 38.6 & 3 & 5.2 \\
\hline
\end{tabular}

${ }^{a}$ Under the assignation probability $P(q l) \geq 80 \%$.

Blanco' in southern Spain; Besnard et al., 2001) probably linked to the ability of PM to adapt to a wide range of contrasting ecological and climatic conditions; (ii) the ancient planting of this variety in traditional orchards, as supported by the study of Charafi et al. (2007) in the Menara gardens, which was established during the 12th century in Morocco, and the extensive propagation of this variety for many centuries.

In contrast, the diversity observed in our study includes genotypes highly distinct from the PM variety. These may have originated from seedlings since the high observed polymorphism was quite similar to that noted within a F1 progeny (distinct by $8-40$ dissimilar alleles; Zine El Aabidine et al., 2010). When comparing the allelic similarity for both the PM variety and highly distinct genotypes from PM with Mediterranean olive cultivars, the closest foreign cultivars were from Spain, Portugal or Italy. This finding could mainly be explained by the geographical proximity to Spain and Portugal and by the historical diffusion of olive cultivation from Italy. The exact origin of such genotypes could be determined by including local wild olives and using more molecular markers.

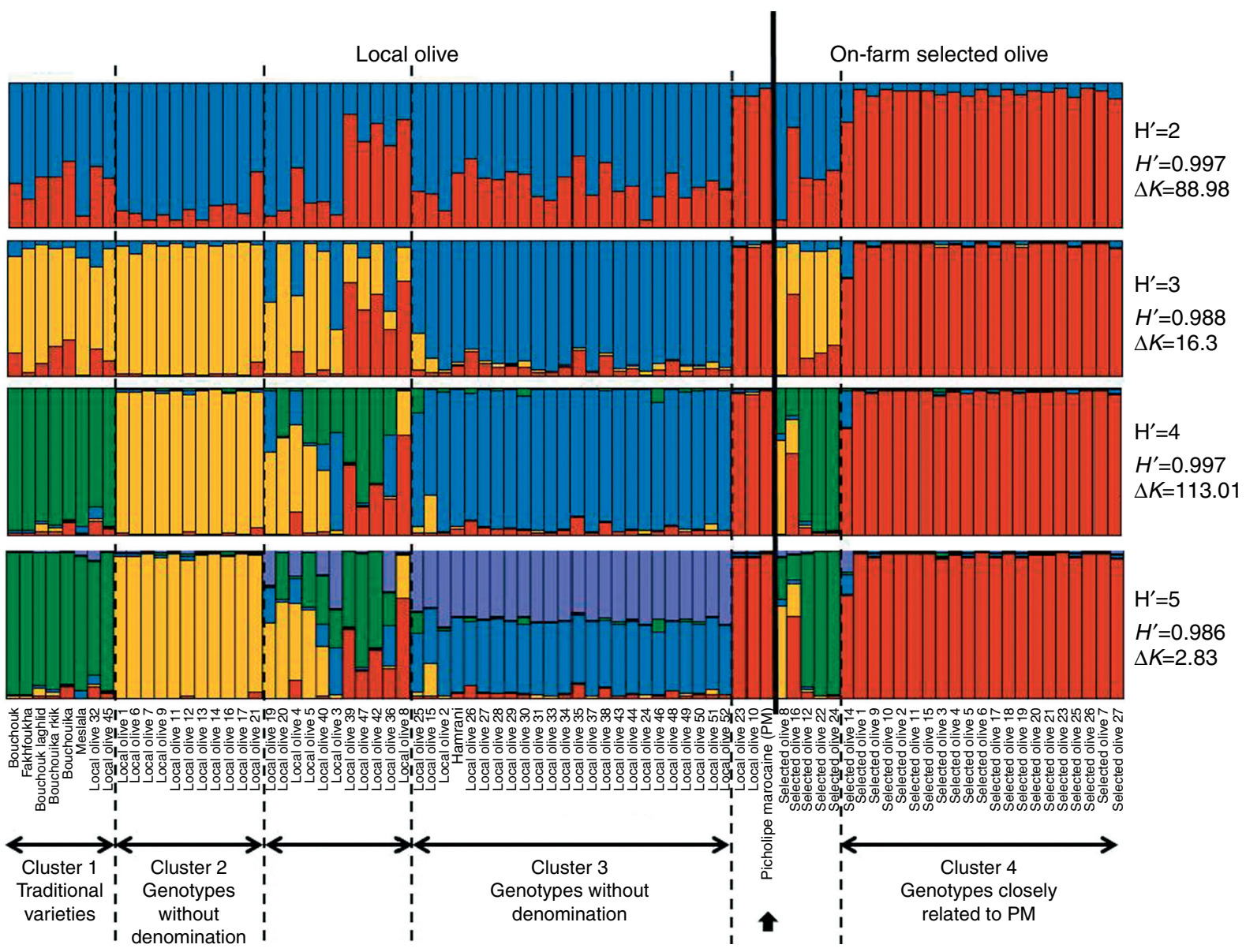

Fig. 3. Genetic structure plot for the total genetic diversity (83 olive genotypes) for $K=2$ to $K=5$. Each bar in the histogram-like graph represents a single individual and its inferred proportion of admixture ( $q$ value). $H^{\prime}$ represents the similarity coefficient between runs for each $K$ and $\Delta K$ represents the ad hoc measure of Evanno et al. (2005). The identification name of each genotype is indicated. Based on $\Delta K$ and $H^{\prime}, K=4$ clusters were revealed as being the best genetic structure model. 
Participatory varietal selection has been advocated as an efficient approach to promote on-farm conservation and maintain a high level of genetic diversity for many annual crop species (Almekinders and Elings, 2001; Zhang et al., 2011). However, studies have shown that genotypes identified by scientists rarely correspond to varieties as perceived by local farmers (Caillon et al., 2006; Barnaud et al., 2007). Here, the approach used to select outstanding trees, by applying farmers' preference criteria, resulted in obtaining genotypes closely related or identical to the PM variety. Haouane et al. (unpublished data) showed that local farmers refer to visible features and agronomic criteria to distinguish between their olive trees but also to the cultural background, including specific community rituals and beliefs. The emphasis on suitable perceptual distinctiveness criteria (Boster, 1985) with agro-morphological traits in breeding programmes and in situ conservation seems important to be able to recognize, manage and make effective use of the genetic resources, especially in low-input farming systems (Gibson et al., 2009).

\section{Conclusion}

The sampling strategy used in our survey was aimed at collecting trees on the basis of farmers' local knowledge through in situ observations of agronomic traits. This strategy allowed us to identify a subset of accessions closely related to the PM variety, probably reflecting somaclonal variations accumulated over time. This finding highlights the need for additional research to validate the somatic mutation hypothesis concerning the origin of genotypes closely related to the PM variety. Multidisciplinary approaches, combining genetic characterization, phenotypic description and ethnobotany analyses, should be used to select olive genotypes highly distinct from the PM variety. In addition, a set of genotypes with attractive agronomic characteristics was identified from locally selected trees, thus providing, for the first time, some evidence of farmers' active participation in fostering and preserving genetic diversity.

\section{Acknowledgements}

All molecular genotyping was performed in the 'Atelier de Marquage Moléculaire' UMR AGAP laboratory. The authors thank all members of the laboratory for their technical support, and particularly Ch. Tollon for her participation in microsatellite genotyping. Dr Ph. Chatelet is also thanked for his kind remarks on an earlier version of the manuscript. The authors are also grateful to Dr A. Bervillé for comments on the final version of the manuscript. This study was supported by PRAD 08-01, IDB Merit Scholarship
Program for High Technology and Agropolis Fondation FruiMed No. 0901-007. A. El Bakkali was supported by fellowships from IDB $1430 \mathrm{H} / 2009$ and PRAD 08-01.

\section{References}

Achak H, Ater M, Oukabli A, Santoni S, Kjellberg F and Khadari B (2010) Traditional agroecosystems as conservatories and incubators of cultivated plant varietal diversity: the case of Fig (Ficus carica L.) in Morocco. BMC Plant Biology 10: 28.

Almekinders CJM and Elings A (2001) Collaboration of farmers and breeders: participatory crop improvement in perspective. Euphytica 122: 425-438.

Baali-Cherif D and Besnard G (2005) High genetic diversity and clonal growth in relict populations of Olea europaea subsp. laperrinei (Oleaceae) from Hoggar Algeria. Annals of Botany 96: 823-830.

Bachtrog D, Agis M, Imhof M and Schlötterer C (2000) Microsatellite variability differs between dinucleotide repeat Motifs - evidence from Drosophila melanogaster. Molecular Biology and Evolution 17: 1277-1285.

Baldoni L, Cultrera NG, Mariotti R, Ricciolini C, Arcioni S, Vendramin GG, Buonamici A, Porceddu A, Sarri V, Ojeda MA, Trujillo I, Rallo L, Belaj A, Perri E, Salimonti A, Muzzalupo I, Casagrande A, Lain O, Messina R and Testolin $\mathrm{R}$ (2009) A consensus list of microsatellite markers for olive genotyping. Molecular Breeding 24: 213-231.

Barnaud A, Monique D, Garine E, Mckey D and Joly $\mathrm{H}$ (2007) Local genetic diversity of sorghum in a village in northern Cameroon: structure and dynamics of landraces. Theoretical and Applied Genetics 114: 237-248.

Barranco ND, Cimato A, Fiorino P, Rallo RL, Touzani A, Castañeda C, Serafini E and Trujillo NI (2000) World Catalogue of Olive Varieties, COI. Madrid: Mundi-Prensa, p. 360.

Bartolini G, Prevost G, Messeri C and Carignani G (1998) Olive Germplasm: Cultivars and World-wide Collections. Rome: FAO Library.

Besnard G, Breton C, Baradat P, Khadari B and Berville A (2001) Variety identification in olive (Olea europaea L.) based on RAPDs. Journal of the American Society for Horticultural Science 126: 668-675.

Boster JS (1985) Selection for perceptual distinctiveness: evidence from Aguaruna cultivars of Manihot esculenta. Economic Botany 39: 310-325.

Boulouha B, Loussert R and Saadi R (1992) Etude de la variabilité phénotypique de la variété population (Picholine Marocaine) dans la région de Haouz. Olivae 43: 30-33.

Caillon S, Quero-Garcia J, Lescure JP and Lebot V (2006) Nature of taro (Colocasia esculenta (L.) Schott) genetic diversity prevalent in a Pacific Ocean island, Vanua Lava, Vanuatu. Genetic Resources and Crop Evolution 53: 1273-1289.

Carriero F, Fontanazza G, Cellini F and Giorio G (2002) Identification of simple sequence repeats (SSRs) in olive (Olea europaea L.). Theoretical and Applied Genetics 104: $301-307$.

Chakraborty R, Kimmel M, Stivers DN, Davison LJ and Deka R (1997) Relative mutation rates at di-, tri-, and tetranucleotide microsatellite loci. Proceedings of the National Academy of Science 94: 1041-1046.

Charafi J, El Meziane A, Moukhli A, Boulouha B, El Modafar C and Khadari B (2007) Menara gardens: a Moroccan olive germplasm collection identified by SSR locus genetic study. Genetic Resources and Crop Evolution 55: 893-900. 
Cipriani G, Marrazzo MT, Marconi R and Cimato A (2002) Microsatellite markers isolated in olive (Olea europaea L.) are suitable for individual fingerprinting and reveal polymorphism within ancient varieties. Theoretical and Applied Genetics 104: 223-228.

De La Rosa R, James CM and Tobutt KR (2002) Isolation and characterization of polymorphic microsatellites in olive (Olea europaea L.) and their transferability to other genera in the Oleaceae. Molecular Ecology Notes 2: 265-267.

Evanno G, Regnaut S and Goudet J (2005) Detecting the number of clusters of individuals using the software Structure, a simulation study. Molecular Ecology 14: 2611-2620.

Fufa F, Baum M, Grando S, Kafawin O and Ceccarelli S (2007) Consequences of a decentralized participatory barley breeding programme on changes in SSR allele frequency and diversity in one cycle of selection. Plant Breeding 126: 527-532.

Fufa F, Grando S, Kafawin O, Shakhatreh Y and Ceccarelli S (2010) Efficiency of farmers' selection in a participatory barley breeding programme in Jordan. Plant Breeding 129: $156-161$.

Gibson RW (2009) A review of perceptual distinctiveness in landraces including an analysis of how its roles have been overlooked in plant breeding for low-input farming systems. Economic Botany 63: 242-255.

Green PS and Wickens GE (1989) The Olea europaea complex. In: Kit Tan (ed.) The Davis \& Hedge Festschrift. Edinburgh: Edinburgh University Press, pp. 287-299.

Haouane H, El Bakkali A, Moukhli A, Tollon C, Santoni S, Oukabli A, El Modafar C and Khadari B (2011) Genetic structure and core collection of the World Olive Germplasm Bank of Marrakech: towards the optimised management and use of Mediterranean olive genetic resources. Genetica 139: 1083-1094.

Ibanez J, Velez MD, De Andres MT and Borrego J (2009) Molecular markers for establishing distinctness in vegetatively propagated crops: a case study in grapevine. Theoretical and Applied Genetics 119: 1214-1222.

Jakobsson M and Rosenberg NA (2007) Clumpp: a cluster matching and permutation program for dealing with label switching and multimodality in analysis of population structure. Bioinformatics 23: 1801-1806.

Khadari B, Charafi J, Moukhli A and Ater M (2008) Substantial genetic diversity in cultivated Moroccan olive despite a single major variety: a paradoxical situation evidenced by the use of SSR loci. Tree Genetics and Genomes 4: 213-221.

Khadari B, Zine El Aabidine A, Grout C, Ben Sadok I, Doligez A, Moutier N, Santoni S and Costes E (2010) A genetic linkage map of olive based on amplified fragment length polymorphism, intersimple sequence repeat and simple sequence repeat markers. Journal of the American Society for Horticultural Science 135: 548-555.

Kruglyak S, Durret RT, Schug M and Aquadro CF (1998) Equilibrium distributions of microsatellite repeat length resulting from a balance between slippage events and point mutations. Proceedings of the National Academy of Science 95: 10774-10778.

Lenoir M and Akerraz A (1984) L'oléiculture dans le Maroc antique. Olivae 3: 12-17.

Lopes MS, Mendonça D, Sefc KM, Gil FS and Machado AC (2004) Genetic evidence of intra-variety variability within Iberian olive varieties. HortScience 39: 1562-1565.

Nei M (1987) Molecular Evolutionary Genetics. New York: Columbia University Press.
Nei M and Li W (1979) Mathematical model for studying genetic variation in terms of restriction endonucleases. Proceedings of the National Academy of Science 76: 5269-5273.

Padula G, Giordani E, Bellini E, Rosati A, Pandolfi S, Paoletti A, Pannelli G, Ripa V, De Rose F, Perri E, Buccoliero A and Mennone C (2008) Field evaluation of new olive (Olea europaea L.) selections and effects of genotype and environment on productivity and fruit characteristics. Advances in Horticultural Science 22: 87-94.

Park SDE (2001) Trypanotolerance in West African cattle and the population genetic effects of selection. PhD Thesis, University of Dublin.

Pritchard JK, Stephens M and Donnelly P (2000) Inference of population structure from multilocus genotype data. Genetics 155: 945-959.

R Development Core Team (2011) R: A Language and Environment for Statistical Computing. Vienna: R Foundation for Statistical Computing. ISBN 3-900051-07-0. URL: http://www.R-project.org/

Rohlf FJ (2000) NTSYS-pc. Numerical Taxonomy and Multivariate Analysis System. New York: Exeter Software.

Sarri V, Baldoni L, Porceddu A, Cultrera NGM, Contento A, Frediani M, Belaj A, Trujillo I and Cionini PG (2006) Microsatellites markers are powerful tools for discriminating among olive varieties and assigning them to geographically defined populations. Genome 49: 1606-1615.

Schug MD, Hutter CM, Wetterstrand KA, Gaudette MS, Mackay TF and Aquadro CF (1998) The mutation rates of di-, triand tetranucleotide repeats in Drosophila melanogaster. Molecular Biology and Evolution 15: 1751-1760.

Sefc KM, Lopes MS, Mendonca D, Rodrigues Dos Santos M, Laimer Da Camara Machado M and Da Camara Machado A (2000) Identification of microsatellite loci in olive (Olea europaea) and their characterization in Italian and Iberian olive trees. Molecular Ecology 9: 1171-1193.

Sneath PHA and Sokal RR (1973) Numerical Taxonomy. San Francisco, CA: WH Freeman.

Szpiech ZA, Jakobsson M and Rosenberg NA (2008) ADZE: a rarefaction approach for counting alleles private to combinations of populations. Bioinformatics 24: 2498-2504.

Tessier C, David J, This P, Boursiquot JM and Charrier A (1999) Optimization of the choice of molecular markers for varietal identification in Vitis vinifera $\mathrm{L}$. Theoretical and Applied Genetics 98: 171-177.

Udupa SM, Robertson LD, Weigand F, Baum M and Kahl G (1999) Allelic variation at (TAA)n microsatellite loci in a world collection of chickpea (Cicer arietinum L.) germplasm. Molecular and General Genetics 261: 354-363.

Zhang D, Arevalo Gardini E, Motilal LA, Baligar V, Bailey B, Zuñiga-Cernades L, Arevalo-Arevalo CE and Meinhardt L (2011) Dissecting genetic structure in farmer selections of Theobroma Cacao in the Peruvian Amazon: implications for on farm conservation and rehabilitation. Tropical Plant Biology 4: 106-116.

Zine El Aabidine A, Charafi J, Grout C, Doligez A, Santoni S, Moukhli A, Jay-Allemand C, El Modafar C and Khadari B (2010) Construction of a genetic linkage map for the olive based on AFLP and SSR markers. Crop Science 50: 2291-2302.

Zohary D and Hopf M (2000) Domestication of Plants in the Old World: The Origin and Spread of Cultivated Plants in West Asia, Europe, and the Nile Valley. New York: Oxford University Press. 